\title{
Pros and Cons of Olive Fertigation: Influence on Fruit and Oil Quality
}

A. Morales-Sillero

Departamento de Ciencias Agroforestales

Universidad de Sevilla

41013-Sevilla

Spain

\author{
J.E. Fernández and A. Troncoso \\ Instituto de Recursos Naturales y \\ Agrobiología (IRNAS-CSIC) \\ Avenida de Reina Mercedes, 10 \\ 41012-Sevilla \\ Spain
}

Keywords: Olea europaea L, oil and fruit quality

\section{Abstract}

Agronomic practices can modify olive fruit and oil quality. However, there is little information on the influence of fertigation, a common practice in most intensive orchards. We studied nutrient distribution in the soil profile following fertigation with different doses of N-P-K fertilizer, and its effect on nutrient concentrations, yield and both table olive and oil quality. Measurements were performed in an adult 'Manzanilla de Sevilla' olive orchard in which 100, 200 and $400 \mathrm{~g} N$ per tree and irrigation period of a $4 \mathrm{~N}-1 \mathrm{P}-3 \mathrm{~K}$ fertilizer were applied by fertigation from 1999 to 2001 (three growing seasons) and 200,400 and $600 \mathrm{~g} N$ of the same fertilizer were applied in the two following growing seasons (2002-2003). A control treatment, irrigation without fertilizer, was also established. Irrigation amounts were similar in all treatments.

In 2003, $\mathrm{NO}_{3}-\mathrm{N}, \mathrm{P}$ and $\mathrm{K}$ concentrations in the root zone wetted by irrigation were studied: they increased with respect to those in the drying zone, showing a general linear relationship with fertilizer dose, particularly in the top soil layer where most of the olive roots were active. In the $600 \mathrm{~g} \mathrm{~N}$ treatment, leaching losses were observed at $0.8-0.9 \mathrm{~m}$ depth, possibly leading to groundwater contamination. We found an increase in fruit yield with increasing fertilizer dose, likely due to the observed greater concentrations of $\mathrm{NO}_{3}-\mathrm{N}, \mathrm{P}$ and $\mathrm{K}$ in the soil. In fact, our data show a positive relationship between increased soil $\mathrm{NO}_{3}-\mathrm{N}, \mathrm{P}$ and $\mathrm{K}$ availability and higher leaf $\mathbf{N}, \mathbf{P}, \mathrm{K}$ concentrations. This could have accounted for the observed increase in canopy volume, fruit number per tree and fruit weight with the amount of fertilizer.

Despite the fact that fruit weight, pulp/stone ratio and volume increased with fertilizer dose, reducing sugars, necessary for olive fermentation, and pulp texture decreased. Differences in texture remained after 'Spanish-style' green olive processing. In addition, no differences were found in oil content but its quality was negatively affected with increasing fertilizer: in particular, polyphenol total content, bitterness, oxidative stability and the relation of monounsaturated/polyunsaturated fatty acids decreased with fertilizer dose.

\section{INTRODUCTION}

Many of the new olive orchards have localized irrigation, which enables highfrequency fertigation. It is assumed that the benefits of fertigation derive from both being able to adjust the water and fertilizer supplied and their application in wetted soil zones where most active roots are located. Fertigation increases both the root growing period and nutrient assimilation (Fernández et al., 1991). Nevertheless, fertigation also has some drawbacks, such as soil nutrient depletion and acidification (Peryea and Burrows, 1999; Mmolawa and Or; 2000; Neilsen et al., 2004). In addition, fertigation may favor $\mathrm{N}_{-} \mathrm{NO}_{3}$ leaching, resulting in nutrient losses and groundwater contamination.

Olive oil and table olive consumption has increased in recent years because of the recognized nutritional value of the Mediterranean diet (Patumi et al., 2002). The table olive industry demands fruits with good size, shape, high pulp/stone ratio, good texture and color. The nutritional and biological value of the fruit depends on some chemical components of its pulp such as water, oil, reducing sugars, polysaccharides, polyphenols 
and minerals. Fruit texture is also important for table olive production (Morales-Sillero et al., 2008).

Factors such as cultivar, weather and soil conditions, fruit ripeness, agronomic practices and oil-extraction process influence the fruit and oil characteristics. Among the agronomic practices, fertigation holds great importance (Morales-Sillero et al., 2007, 2008).

\section{MATERIALS AND METHODS}

The experiment was carried out from 1999 to 2003 in a 'Manzanilla' olive orchard close to Seville in Spain. The trees, at $7 \mathrm{~m} \mathrm{x} 7 \mathrm{~m}$ spacing, were 10 years old in 1999. A randomized complete block design with six blocks per treatment (repetitions) and four trees per block was established. Each block was surrounded by guard trees.

The trees received 100, 200 and $400 \mathrm{~g}$ of $\mathrm{N}$ per tree and irrigation period with $4 \mathrm{~N}$ 1P-3K fertilizer that was applied by fertigation from 1999 to 2001 (three summer growing seasons) and 200, 400 and $600 \mathrm{~g}$ of $\mathrm{N}$ per tree of the same fertilizer in the two following summer growing seasons (2002-2003); these treatments were named T200, T400 and T600, respectively. A control treatment, irrigated but without fertilizer, was also established. Irrigation amounts were calculated according to crop evapotranspiration $\left(\mathrm{ET}_{\mathrm{c}}\right)$ estimated by the crop coefficient approach (Allen et al., 1998), using the $K_{r}$ and $K_{c}$ coefficient values estimated for this orchard by Fernández et al. (2006) $\left(K_{r}=0.7 ; K_{c}\right.$ values were 0.76 in May, 0.70 in June, 0.63 in July and August, 0.72 in September and 0.77 in October).

The methods used for root-distribution, soil and plant analyses were as described by Morales-Sillero et al. (2009). Fruit quality was evaluated according to Morales-Sillero et al. (2008), and oil quality was characterized as described by Morales-Sillero et al. (2007).

Analysis of variance (ANOVA) was used to determine statistical differences between treatments of all studied variables, and analysis of covariance was used for fruit yield. Polynomial contrasts were obtained when a significant $F$ test was observed.

\section{RESULTS AND DISCUSSION}

\section{Fertigation and Soil-Plant Interactions}

The average estimated evapotranspiration was $250 \mathrm{~mm}$ per irrigation season. Hence, each tree received the same quantity of irrigation water, enough to maintain the soil close to field capacity. The soil outside the wetted zone was under drying conditions, since no rain fell during the summer seasons. We estimated that about $81 \%$ of the young active roots were located in the wet zones. Similar results were reported by Fernández et al. (1991).

The soil concentrations of $\mathrm{N}^{-\mathrm{NO}_{3}}$ and available $\mathrm{P}$ and $\mathrm{K}$ showed a linear increase with fertilizer dose (Table 1), which was less evident at increasing soil depth. The high contents of $\mathrm{N}-\mathrm{NO}_{3}$ recorded in the T600 trees at 80-90 cm depth, together with the absence of active roots, indicated a significant risk of groundwater contamination by nitrate leakage.

The contents of N, P and $\mathrm{K}$ in the leaves showed a linear increase with treatment dose, likely because of the increasing availability of these elements in the soil. It should be noted that $\mathrm{N}$ and $\mathrm{K}$, but not $\mathrm{P}$ levels were low in the control trees prior to irrigation (Table 2).

The increasing fertilizer dose increased total fruit production, but the average fruit weight was not significantly affected. Nevertheless, there was a tendency toward increasing fruit weight with fertilizer dose, parallel to the increase in fruit yield (Table 3). 


\section{Fertigation and Table Olive Quality}

Data on fruit quality correspond only to the last experimental year (2003). The contents of $\mathrm{K}$ in the fruits increased with the fertilizer dose, while those of $\mathrm{Na}$ and $\mathrm{B}$ decreased (Table 4). The rest of the nutrients studied showed no significant differences among treatments.

The fruit weight and volume, longitudinal and equatorial diameters, and pulp/ stone ratio increased with fertilizer dose, without altering the fruit's shape (Table 5). These fruit features are valued by consumers, and are therefore favorably considered in the table olive industry.

On the other hand, the increasing fertilizer dose negatively affected other fruit characteristics important for table olive production, such as water content, reducing sugar and polyphenol concentrations, and fruit texture (Table 6).

\section{Fertigation and Olive Oil Quality}

As with table fruit quality, data on oil quality correspond only to the last experimental year. We observed no significant differences in the oil contents of fresh fruits, but the increase in crop production with fertilizer dose led to a significant increase in oil yield (Table 7).

The polyphenol content, $\mathrm{K}_{225}$ (bitterness) and oil oxidative stability decreased significantly with the fertilizer dose (Table 7). Increasing fertilizer dose significantly decreased the ratio of monounsaturated to polyunsaturated acids (Table 8). In particular, the percentage of oleic acid was decreased by the treatments while linoleic and linolenic acids increased.

The fertigation treatments did not significantly modify or only inconsistently modified the factors shown in Table 9.

\section{CONCLUSIONS}

Pros of the fertigation treatments:

- Increase in $\mathrm{N}-\mathrm{NO}_{3}$ and available $\mathrm{K}$ and $\mathrm{P}$ contents and consequent improvement of plant nutritional status.

Increase in total fruit production, fruit weight, and fruit volume through lengthening of the longitudinal and equatorial diameters without altering shape, and increased pulp/stone ratio and $\mathrm{K}$ content.

Cons of the fertigation treatments:

- Increase in fruit water content, deterioration in texture, and decreased reducing sugar and polyphenol concentrations, bitterness $\left(\mathrm{K}_{225}\right)$ and oil oxidative stability.

- Decrease of mono/polyunsaturated acids ratio in oil and in particular a reduction in oleic acid, and an increase in linoleic and linolenic acids.

Therefore, it is important to control fertigation treatments.

\section{Literature Cited}

Allen, R., Pereira, L.S., Raes, D. and Smith, M. 1998. Crop evapotranspiration: guidelines for computing crop water requirements. FAO Irrigation and Drainage Paper 56. FAO, Rome.

Fernández, J.E., Díaz-Espejo, A., Infante, J.M., Durán, P., Palomo, M.J., Chamorro, V., Girón, I.F. and Villagarcía, L. 2006. Water relations and gas exchange in olive trees under regulated deficit irrigation and partial rootzone drying. Plant Soil 284:273-291.

Fernández, J.E., Moreno, F., Cabrera, F., Arrúe, J.L. and Martín-Aranda, J. 1991. Drip irrigation, soil characteristics and the root distribution and root activity of olive trees. Plant Soil 133:239-251.

Mmolawa, K. and Or, D. 2000. Root zone solute dynamics under drip irrigation: a review. Plant Soil 222:163-190.

Morales-Sillero, A., Fernández, J.E., Beltrán, G., Jiménez, R. and Troncoso, A. 2007. Influence of fertigation in 'Manzanilla de Sevilla' olive oil quality. HortScience 42:1157-1162. 
Morales-Sillero, A., Fernández, J.E., Ordovás, J., Suárez, M.P., Pérez, J.A., Liñán, J., López, E.P., Girón, I. and Troncoso, A. 2009. Plant-soil interactions in a fertigated 'Manzanilla de Sevilla' olive orchard. Plant Soil 319:147-162.

Morales-Sillero, A., Fernández, J.E., Rejano, L., Jiménez, R. and Troncoso, A. 2008. Effect of fertigation on the 'Manzanilla de Sevilla' table olive quality before and after 'Spanish-style' olive processing. HortScience 43:153-158.

Neilsen, G.H., Neilsen, D., Herbert, L.C. and Hogue, E.J. 2004. Response of apple to fertigation of $\mathrm{N}$ and $\mathrm{K}$ under conditions susceptible to the development of $\mathrm{K}$ deficiency. J. Amer. Soc. Hort. Sci. 129:26-31.

Patumi, M., d’Andria, R., Marsilio, V., Fontanazza, G., Morelli, G. and Lanza, B. 2002. Olive and olive oil quality after intensive monocone olive growing (Olea europaea L. cv. Kalamata) in different irrigation regimes. Food Chem. 77:27-34.

Peryea, F.J. and Burrows, R.L. 1999. Soil acidification caused by four commercial nitrogen fertilizer solutions and subsequent soil $\mathrm{pH}$ rebound. Commun. Soil Sci. Plant Anal. 30:525-533.

\section{Tables}

Table 1. Mean values $\left(\mathrm{n}=3\right.$ ) of $\mathrm{N}-\mathrm{NO}_{3}$, extractable $\mathrm{P}$ and exchangeable $\mathrm{K}$ in the profile of the area of influence of the soil wetted bulb before (31 Mar) and during (28 Jul) fertigation (data from 2003, the last year of the experiment). Source: Morales-Sillero et al., 2009.

\begin{tabular}{lcccccc}
\hline \multirow{2}{*}{$\begin{array}{l}\text { Soil } \\
\text { depth } \\
\text { (cm) }\end{array}$} & \multicolumn{3}{c}{ Before fertigation } & \multicolumn{3}{c}{ Fertigation } \\
\cline { 2 - 6 } & T-control & T-200 & T-600 & T-control & T-200 & T-600 \\
\hline $10-20$ & $5 \pm 1$ & $5 \pm 1$ & $5 \pm 2$ & $5 \pm 1$ & $12 \pm 5$ & $54 \pm 31$ \\
$40-50$ & $4 \pm 1$ & $3 \pm 0$ & $3 \pm 0$ & $4 \pm 2$ & $6 \pm 2$ & $25 \pm 11$ \\
$80-90$ & $3 \pm 0$ & $3 \pm 0$ & $3 \pm 0$ & $4 \pm 1$ & $6 \pm 3$ & $17 \pm 2$ \\
\hline \multicolumn{7}{c}{$\mathrm{P}(\mathrm{mg} / \mathrm{kg})$} \\
\hline $10-20$ & $8 \pm 4$ & $5 \pm 1$ & $11 \pm 12$ & $16 \pm 22$ & $7 \pm 4$ & $49 \pm 31$ \\
$40-50$ & $5 \pm 3$ & $2 \pm 1$ & $3 \pm 2$ & $5 \pm 2$ & $3 \pm 1$ & $16 \pm 24$ \\
$80-90$ & $4 \pm 2$ & $1 \pm 1$ & $4 \pm 2$ & $2 \pm 0$ & $2 \pm 0$ & $2 \pm 3$ \\
\hline \multicolumn{7}{c}{$\mathrm{K}(\mathrm{mg} / \mathrm{kg})$} \\
\hline $10-20$ & $93 \pm 39$ & $97 \pm 20$ & $137 \pm 49$ & $91 \pm 38$ & $122 \pm 9$ & $281 \pm 58$ \\
$40-50$ & $57 \pm 31$ & $44 \pm 18$ & $94 \pm 10$ & $53 \pm 17$ & $41 \pm 8$ & $114 \pm 55$ \\
$80-90$ & $38 \pm 13$ & $45 \pm 17$ & $53 \pm 17$ & $30 \pm 17$ & $51 \pm 6$ & $74 \pm 26$ \\
\hline
\end{tabular}

Table 2. Leaf contents (\% DW) of N, P, and K before (July 1998) and after (July 2003) treatments $(n=6)$. Source: Morales-Sillero et al., 2009.

\begin{tabular}{lcccccc}
\hline \multirow{2}{*}{ Treatment } & \multicolumn{3}{c}{ Before fertigation } & \multicolumn{3}{c}{ Fertigation } \\
\cline { 2 - 7 } & $\mathrm{N}$ & $\mathrm{P}$ & $\mathrm{K}$ & $\mathrm{N}$ & $\mathrm{P}$ & $\mathrm{K}$ \\
\hline T-control & 1.27 & 0.11 & 0.60 & 1.26 & 0.10 & 0.64 \\
T-200 & 1.16 & 0.10 & 0.60 & 1.22 & 0.11 & 0.76 \\
T-400 & 1.27 & 0.11 & 0.66 & 1.56 & 0.12 & 0.96 \\
T-600 & 1.27 & 0.10 & 0.67 & 1.57 & 0.12 & 1.09 \\
\hline Significance $^{\mathrm{z}, \mathrm{y}}$ & $\mathrm{NS}$ & $\mathrm{NS}$ & $\mathrm{NS}$ & $\mathrm{L}^{* *}, \mathrm{C}^{* *}$ & $\mathrm{~L}^{*}$ & $\mathrm{~L}^{* * * *}$ \\
CV (\%) & 9.5 & 6.9 & 13.4 & 6.2 & 9.3 & 15.3 \\
\hline
\end{tabular}

${ }^{\mathrm{z}}$ NS, not significant; *, **, ****, significant at $P \leq 0.05,0.01$ and 0.0001 , respectively.

${ }^{\mathrm{y}} \mathrm{L}$, linear; C, cubic.

${ }^{\mathrm{x}} \mathrm{CV}$, coefficient of variation. 
Table 3. Total fruit production and average fruit weight $(n=6)$ from 1999 to 2003. Total production data are from Morales-Sillero et al., 2009.

\begin{tabular}{lcc}
\hline Treatment & $\begin{array}{c}\text { Total production } \\
\text { (kg/tree) }\end{array}$ & $\begin{array}{c}\text { Average fruit } \\
\text { weight }(\mathrm{g})\end{array}$ \\
\hline T-control & 77.66 & 4.08 \\
T-200 & 91.40 & 4.20 \\
T-400 & 93.58 & 4.25 \\
T-600 & 97.73 & 4.44 \\
\hline Significance ${ }^{\mathrm{z}, \mathrm{y}}$ & $\mathrm{L}^{* *}$ & $\mathrm{NS}$ \\
CV $(\%)^{\mathrm{x}}$ & 37.1 & 9.2 \\
\hline
\end{tabular}

${ }^{\mathrm{z}}$ NS, not significant; **, significant at $P \leq 0.01$.

${ }^{\mathrm{y}} \mathrm{L}$, linear.

${ }^{\mathrm{x}} \mathrm{CV}$, coefficient of variation.

Table 4. Influence of the fertigation treatments on fruit nutrient composition $(\mathrm{n}=6)(\mathrm{data}$ from September 2003). Source: Morales-Sillero et al., 2008.

\begin{tabular}{|c|c|c|c|c|c|c|c|c|c|c|c|c|}
\hline \multirow{2}{*}{ Treatment } & \multicolumn{7}{|c|}{$\mathrm{g} / \mathrm{kg}$} & \multicolumn{5}{|c|}{$\mathrm{mg} / \mathrm{kg}$} \\
\hline & $\mathrm{N}$ & $\mathrm{P}$ & $\mathrm{K}$ & $\mathrm{Ca}$ & $\mathrm{Mg}$ & $\mathrm{Na}$ & $\mathrm{S}$ & $\mathrm{Fe}$ & $\mathrm{Cu}$ & $\mathrm{Mn}$ & $\mathrm{Zn}$ & $B$ \\
\hline T-control & 6.9 & 1.4 & 13.5 & 1.7 & 0.3 & 0.3 & 0.2 & 18.6 & 10.0 & 5.2 & 15.0 & 22.6 \\
\hline T-200 & 7.4 & 1.3 & 13.6 & 1.6 & 0.3 & 0.1 & 0.2 & 16.6 & 9.6 & 4.6 & 11.6 & 17.2 \\
\hline T-400 & 8.4 & 1.2 & 15.5 & 1.2 & 0.3 & 0.1 & 0.3 & 19.3 & 4.7 & 4.2 & 10.7 & 9.8 \\
\hline $\mathrm{T}-600$ & 7.7 & 1.3 & 16.2 & 1.2 & 0.3 & 0.1 & 0.3 & 18.0 & 6.6 & 4.4 & 11.4 & 9.7 \\
\hline Signifi & NS & NS & $\mathrm{L}^{* *}$ & $\mathrm{~L}^{*}$ & NS & $\mathrm{L}^{* *}$ & NS & NS & NS & NS & NS & $\mathrm{L}^{* *}$ \\
\hline $\mathrm{CV}(\%$ & 9.2 & 19.5 & 10.2 & 18.1 & 23.1 & 56.4 & 17.3 & 29. & 65.8 & 23.9 & 19.3 & 39.7 \\
\hline
\end{tabular}

${ }^{\mathrm{z}}$ NS, non significant; *, **, significant at $P \leq 0.05$, and 0.01 , respectively.

${ }^{\mathrm{y}} \mathrm{L}$, linear.

${ }^{\mathrm{x}} \mathrm{CV}$, coefficient of variation.

Table 5. Influence of fertigation treatments on fruit size and shape $(n=6)$ (data from September 2003). Source: Morales-Sillero et al., 2008.

\begin{tabular}{lcccccc}
\hline Treatment & $\begin{array}{c}\text { Weight } \\
(\mathrm{g})\end{array}$ & $\begin{array}{c}\text { Volume } \\
(\mathrm{ml})\end{array}$ & $\begin{array}{c}\text { Length } \\
(\mathrm{mm})\end{array}$ & $\begin{array}{c}\text { Width } \\
(\mathrm{mm})\end{array}$ & $\begin{array}{c}\text { Shape } \\
\text { T-control }\end{array}$ & $\begin{array}{c}\text { Pulp/stone } \\
\text { ratio }\end{array}$ \\
T-200 & 4.25 & 4.02 & 21.0 & 18.1 & 1.2 & 5.12 \\
T-400 & 4.21 & 4.33 & 21.5 & 18.4 & 1.2 & 5.83 \\
T-600 & 4.81 & 4.75 & 22.2 & 18.9 & 1.2 & 6.41 \\
\hline Significance & 5.03 & 4.94 & 22.6 & 19.3 & 1.2 & 6.65 \\
CV $(\%)^{\mathrm{x}}$ & $\mathrm{L}^{* * *}$ & $\mathrm{~L}^{* * *}$ & $\mathrm{~L}^{* *}$ & $\mathrm{~L}^{* * *}$ & $\mathrm{NS}$ & $\mathrm{L}^{* * * *}$ \\
\hline
\end{tabular}

${ }^{\mathrm{z}}$ NS, not significant; ${ }^{* *}, * * *, * * * *$, significant at $P \leq 0.01,0.001$, and 0.0001 , respectively.

${ }^{\mathrm{y}} \mathrm{L}$, linear.

${ }^{\mathrm{x}} \mathrm{CV}$, coefficient of variation. 
Table 6. Influence of the fertigation treatments on some chemical characteristics of the fruits $(n=6)$ (data from September 2003). Source: Morales-Sillero et al., 2008.

\begin{tabular}{|c|c|c|c|c|c|c|}
\hline \multirow[t]{2}{*}{ Treatment } & \multirow{2}{*}{$\begin{array}{c}\text { Water } \\
\text { content } \\
(\%)\end{array}$} & \multicolumn{2}{|c|}{$\begin{array}{c}\text { Reducing sugars } \\
(\%)\end{array}$} & \multicolumn{2}{|c|}{$\begin{array}{c}\text { Polyphenol } \\
\text { (mg/kg caffeic acid) }\end{array}$} & \multirow[t]{2}{*}{$\begin{array}{l}\text { Texture } \\
\text { (N/g) }\end{array}$} \\
\hline & & FW & DW & FW & DW & \\
\hline T-control & 58.7 & 4.4 & 10.6 & 27,2 & 66,0 & 92.1 \\
\hline T-200 & 58.3 & 4.7 & 11.2 & 27,3 & 65,7 & 86.6 \\
\hline T-400 & 62.4 & 3.4 & 8.9 & 25,4 & 67,8 & 77.8 \\
\hline T-600 & 63.1 & 3.2 & 8.9 & 24,1 & 65,3 & 77.0 \\
\hline Significance ${ }^{z, y}$ & $\mathrm{~L}^{* * *}, \mathrm{C}^{* *}$ & $L^{* *}, C^{* *}$ & $\mathrm{~L}^{*}$ & $\mathrm{~L}^{* * *}$ & NS & $\mathrm{L}^{* *}$ \\
\hline CV $(\%)^{x}$ & 2.3 & 13.4 & 13.0 & 5.5 & 2.1 & 6.3 \\
\hline
\end{tabular}

${ }^{\mathrm{z}} \mathrm{NS}$, not significant; ${ }^{*}, * *, * * *$, significant at $P \leq 0.05,0.01$, and 0.001 , respectively.

${ }^{\mathrm{y}} \mathrm{L}$, linear; C, cubic.

${ }^{\mathrm{x}} \mathrm{CV}$, coefficient of variation.

Table 7. Fruit oil content and yield, and polyphenol content, $\mathrm{K}_{225}$, and oxidative stability of virgin oil from each fertigation treatment $(n=6)$ and for the last experimental season (data from September 2003). Source: Morales-Sillero et al., 2007.

\begin{tabular}{|c|c|c|c|c|c|c|}
\hline \multirow[t]{2}{*}{ Treatment } & \multicolumn{2}{|c|}{ Oil content } & \multirow{2}{*}{$\begin{array}{c}\text { Oil } \\
\text { yield } \\
\text { (g/ha) }\end{array}$} & \multirow{2}{*}{$\begin{array}{c}\text { Polyphenol } \\
\text { content } \\
\text { (mg/kg) }\end{array}$} & \multirow[t]{2}{*}{$\mathrm{K}_{225}$} & \multirow{2}{*}{$\begin{array}{l}\text { Oxidative } \\
\text { stability } \\
\text { (h) }\end{array}$} \\
\hline & \% FW & \% DW & & & & \\
\hline T-control & 13.26 & 32.13 & 112.2 & 1272 & 0.54 & 154 \\
\hline $\mathrm{T}-200$ & 14.83 & 35.47 & 183.6 & 1281 & 0.53 & 148 \\
\hline T-400 & 13.45 & 35.72 & 222.4 & 794 & 0.41 & 97 \\
\hline T-600 & 12.55 & 34.20 & 230.5 & 860 & 0.48 & 103 \\
\hline Significance $^{\mathrm{z}, \mathrm{y}}$ & NS & NS & $\mathrm{L}^{*}$ & $\mathrm{~L}^{* * *}, \mathrm{C}^{* *}$ & $\mathrm{C}^{* *}, \mathrm{~L}^{*}$ & $\mathrm{~L}^{* * *}, \mathrm{C}^{* *}$ \\
\hline CV (\%) & 10.4 & 7.8 & 38.7 & 12.3 & 6.5 & 10.4 \\
\hline
\end{tabular}

${ }^{\mathrm{z}} \mathrm{NS}$, not significant; ${ }^{*}, * *, * * *$, significant at $P \leq 0.05,0.01$ and 0.001 , respectively.

${ }^{\mathrm{y}} \mathrm{L}$, linear; C, cubic.

${ }^{\mathrm{x}} \mathrm{CV}$, coefficient of variation.

Table 8. Percentage of fatty acids in the oil significantly modified by the fertigation treatments, for the last experimental season (data from September 2003). Source: Morales-Sillero et al., 2007.

\begin{tabular}{|c|c|c|c|c|}
\hline Treatment & $\begin{array}{l}\text { Mono/Polyunsat. } \\
\text { acids ratio }\end{array}$ & $\begin{array}{c}\text { C'18 } \\
\text { oleic acid }\end{array}$ & $\begin{array}{l}\text { C”18 linoleic } \\
\text { acid }\end{array}$ & $\begin{array}{l}\text { C"'18 linolenic } \\
\text { acid }\end{array}$ \\
\hline T-control & 14.82 & 72.21 & 4.25 & 0.81 \\
\hline $\mathrm{T}-200$ & 13.72 & 72.08 & 4.78 & 0.73 \\
\hline T-400 & 9.93 & 70.10 & 6.58 & 0.83 \\
\hline T-600 & 9.63 & 70.02 & 6.34 & 0.87 \\
\hline Significance ${ }^{\mathrm{z}, \mathrm{y}}$ & $\mathrm{L}^{* * *}, \mathrm{C}^{*}$ & $\mathrm{~L}^{* *}, \mathrm{C}^{*}$ & $\mathrm{~L}^{* * *}, \mathrm{C}^{*}$ & $\mathrm{C}^{*}, \mathrm{Q}^{*}$ \\
\hline $\mathrm{CV}(\%)^{\mathrm{x}}$ & 11.7 & 1.2 & 11.1 & 5.5 \\
\hline
\end{tabular}

$\mathrm{z} *$, **, ***, significant at $P \leq 0.05,0.01$, and 0.001 , respectively.

${ }^{\mathrm{y}} \mathrm{L}$, linear; Q, quadratic; C, cubic.

${ }^{\mathrm{x}} \mathrm{CV}$, coefficient of variation. 
Table 9. Oil characteristics not significantly or inconsistently modified by fertigation treatments in the last year of experimentation (average of treatments).

\begin{tabular}{lrc}
\hline $\begin{array}{l}\text { Components not significantly modified by } \\
\text { the treatments }\end{array}$ & $\begin{array}{c}\text { Features modified } \\
\text { inconsistently }\end{array}$ \\
\hline Total unsaturated fatty acids (\%) & 79.61 & Acidity \\
Saturated acids (\%) & 20.35 & Peroxide value \\
C $_{16}$ - Palmitic acid (\%) & 17.24 & $\mathrm{~K}_{232}$ \\
C $^{\prime}{ }_{16}$ - Palmitoleic acid (\%) & 1.70 & $\mathrm{~K}_{270}$ \\
C $_{17}$ - Margaric acid (\%) & 0.14 & \\
CC$^{\prime} 17$ - Heptadecenoic acid (\%) & 0.27 & \\
C $_{18}$ - Stearic acid (\%) & 2.34 & \\
C $_{20}$ - Arachidic acid (\%) & 0.48 & \\
CC$^{\prime}$ - - Gadoleic acid (\%) & 0.28 & \\
C $_{22}$ - Behenic acid (\%) & 0.10 & \\
Tocopherols (mg/kg) & & \\
$\alpha$ & 254 & \\
$\beta$ & 10 & \\
$\gamma$ & 13 & \\
Total & 277 & \\
\hline
\end{tabular}

